\title{
IDŐJÁRÁS
}

Quarterly Journal of the Hungarian Meteorological Service

Vol. 124, No. 3, July-September, 2020, pp. 331-347

\section{Influence of extreme climate conditions on the forest fire risk in the Timočka Krajina region (northeastern Serbia)}

\author{
Ivana Tošić ${ }^{1 *}$, Stanimir Živanović ${ }^{2}$, and Milica Tošić ${ }^{1}$ \\ ${ }^{1}$ University of Belgrade-Faculty of Physics \\ Institute for Meteorology \\ Dobračina 16, 11000 Belgrade, Serbia \\ ${ }^{2}$ Emergency Management Sector of Serbia \\ Omladinskih brigada 31, 11000 Belgrade, Serbia \\ *Corresponding author E-mail:itosic@ff.bg.ac.rs
}

(Manuscript received in final form September 3, 2019)

\begin{abstract}
The dependence of the influence of extreme climate conditions on the variability of forest fires in the Timočka Krajina region of northeastern Serbia was studied. The impact of extreme conditions was investigated with extreme climate indices using air temperature, relative humidity, and precipitation measured at three meteorological stations in northeastern Serbia. The De Martonne index was used to analyze climate conditions as a measure for aridity. The study analyzes trends in extreme climate indices with an emphasis on the two contrasting years, 2012 and 2014, and compares them to the baseline period 1961-1990. The year 2012 was very warm and dry, while 2014 was one of the wettest recorded in Serbia. There was an increase (decrease) in warm (cold) temperature indices. Non-significant increases in extreme precipitation indices were observed, while the number of precipitation events greater than $1 \mathrm{~mm}$ decreased, as did relative humidity.

Angström index values were used as an index for assessing the risk of forest fires. These indices were analyzed and a correlation between them and forest fires in northeastern Serbia was established. The aridity index was low during the years 2012, 2011, and 2017, correlating with the large number of forest fires. High values of the Ångström index in 2013 and 2014 were associated with a minimum number of registered forest fires. As an improved indicator for the number of forest fires, the modified Ångström index using daily maximum temperature is proposed.

pKey-words: extreme climate indices, air temperature, precipitation, forest fires, Key-words: extreme climate indices, air temperature, precipitation, forest fires, Timočka Krajina region, Serbia
\end{abstract}




\section{Introduction}

There is a general agreement that changes in the frequency or intensity of extreme weather and climate events will have profound impacts on both human society and natural environment (Easterling et al., 2000). Every region of the world is already experiencing extreme events (e.g., Yan et al., 2002; Bartholy and Pongrácz, 2007; Santos et al., 2011; Finkel and Katz, 2018).

Forest resources are becoming increasingly sensitive to extremes and climatic conditions. The interest of the competent services for the protection of forests from fires usually focuses on extreme indicators of fire danger. The territory of Serbia is exposed to extreme climate conditions, which are more pronounced in the 21st century (Vuković et al., 2018). The Fourth Assesment Report (AR4) from the Intergovernmental Panel on Climate Change (IPCC, 2007) defines an extreme event as rare at a particular place and time during the year. The implications of extreme climatic events depend on their intensity, duration, and frequency of occurrence. Heat waves, droughts, and storms can have a devastating and a wide range of impacts on forest resources. Fire danger is greater if the dry season is longer, especially during periods when the air temperature is extremely high. Many studies (e.g., Moritz, 2003; McKenzie et al., 2004; Keeley, 2004) indicate that prolonged drought combined with extreme weather conditions, such as high air temperature, wind speed, and low relative humidity, often lead to fires. Drought is relatively common in the northeastern region of Serbia (Aleksić et al., 2004) and it increases the risk of fires of combustible materials. Applying the De Martonne aridity index for 26 meteorological stations in central Serbia, Radakovic et al. (2018) showed that humidity decreases towards the east. Vegetation drying that reduces the moisture content in fuel material creates conditions favorable for the occurrence and spread of fire (Živanović, 2017). Studies from domestic and foreign authors (Popović et al., 2005, 2008; Kadović and Medarević, 2007; Seidling, 2007; Carnicer et al., 2011; De la Cruz et al., 2014) suggest that the impacts of climate change extremes, such as heat waves and droughts, significantly contribute to the exposure and vulnerability of certain ecosystems. The predicted changes in temperature and precipitation regime in Serbia (Djurdjevic et al., 2015; Vukovic et al., 2018) suggest that climate changes in the near or distant future may have even stronger impacts on forest ecosystems and the whole environment.

The appearance of fire in Serbia changes from period to period and largely depends on weather conditions and the humidity of combustible materials (Tabaković-Tošić et al., 2009; Živanović et al., 2018). Variability in climate elements indicates when and to what extent there is a risk of the emergence and spread of fire in the forest (Živanović, 2012; 2015).

Air temperatures over $25^{\circ} \mathrm{C}$ present an elevated risk for the occurrence and spread of forest fires. Some areas in the northeastern territory of Serbia can 
experience more than 26 days a month when air temperature is over $25^{\circ} \mathrm{C}$, creating favorable conditions for the occurrence of forest fires (Vasić, 1992). Particularly dangerous forest fire risk is present during days without atmospheric precipitation and air temperature greater than $30^{\circ} \mathrm{C}$ (Živanović et al., 2015). Some areas in the summer months can experience more than 15 consecutive days with air temperatures greater than $30^{\circ} \mathrm{C}$, greatly exacerbating the danger for forest fires.

The aim of this study is to determine the vulnerability of forest resources to fire on the basis of extreme climate conditions in the Timočka Krajina region. The results are useful as planning criteria to manage adaptation to extreme climate conditions and reduce the future risk of forest fires.

\section{The study area}

Timočka Krajina is located in the northeastern (NE) region of the Republic of Serbia, between $21^{\circ} 40^{\prime}$ to $22^{\circ} 46^{\prime} \mathrm{E}$, and $43^{\circ} 20^{\prime}$ to $44^{\circ} 42^{\prime} \mathrm{N}$ (Fig. 1). Timočka Krajina is the geographic area from which the water is flowing into all five Timok (Svrljiški, Trgoviški, Beli, Crni Timok, and Veliki Timok) originates. The Timok region is separated by several natural boundaries, including on the Danube River on the north, the Stara Planina (Old Mountain) and Veliki Timok River to the east (with Bulgaria), the mountain range from Gramade and Svrljiške mountains to Midžor to the south, and the Severnokučajske Mountains to the west (Manojlović, 1986). In the area of Timok region $\left(7,130 \mathrm{~km}^{2}\right)$, there are two administrative-territorial units, the Bor and Zaječar districts. Specific places and their locations and altitudes are listed in Table 1. There are 249,959 residents in this area.

The Timok forested area in 2008 was $3014.79 \mathrm{~km}^{2}$ covering $42.28 \%$ of the territory. Forest cover ranges from a minimum of $25.28 \%$ in Negotin to $86.47 \%$ in the municipality of Majdanpek. The northeast part of the Republic of Serbia is the Djerdap National Park with nearly untouched flora and fauna. The forest cover stock is large (over 64\%) and has an extremely rich and diverse flora (more than 1,100 plant species) and fauna, which carries all the marks of relictness.

The forests are primarily hardwood (76.13\%) consisting of $38 \%$ beech wood, which is the dominant forest type. Coniferous forests are underrepresented and occupy less than $5 \%$ of the forest fund (RZS, 2008). In accordance with general European floras, floral elements of the area belong to a pontic South-Siberian group within the Pannonian-Vlach subregion, though some other groups (e.g., sub-Mediterranean, Central European) are represented as a result from migration processes (Stevanović, 1999). 


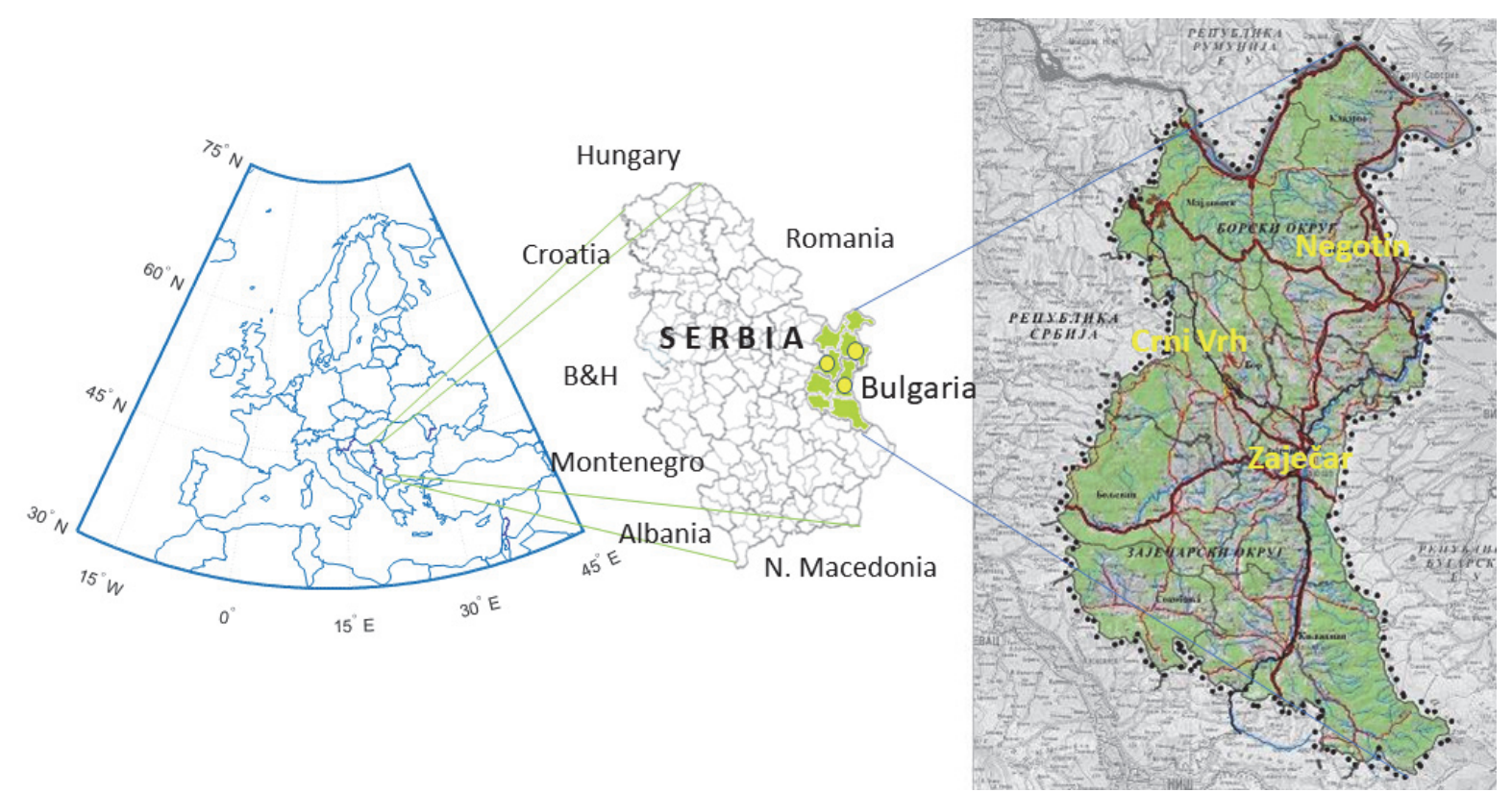

Fig. 1. Timočka Krajina region in northeastern Serbia with location of meteorological stations: Zaječar, Negotin, and Crni Vrh.

Table 1. Geographical location of places in Timočka Krajina with altitude

\begin{tabular}{lccc}
\hline \hline Place & Latitude $(\varphi)$ & Longitude $(\lambda)$ & Altitude $[\mathrm{m}]$ \\
\hline \hline Crni Vrh & $44^{\circ} 07^{\prime} \mathrm{N}$ & $21^{\circ} 57^{\prime} \mathrm{E}$ & 1037 \\
Negotin & $44^{\circ} 13^{\prime} \mathrm{N}$ & $22^{\circ} 31^{\prime} \mathrm{E}$ & 42 \\
Zaječar & $43^{\circ} 53^{\prime} \mathrm{N}$ & $22^{\circ} 18^{\prime} \mathrm{E}$ & 144 \\
Bor & $44^{\circ} 05^{\prime} \mathrm{N}$ & $22^{\circ} 06^{\prime} \mathrm{E}$ & 378 \\
Knjaževac & $43^{\circ} 30^{\prime} \mathrm{N}$ & $22^{\circ} 06^{\prime} \mathrm{E}$ & 276 \\
Sokobanja & $43^{\circ} 39^{\prime} \mathrm{N}$ & $21^{\circ} 52^{\prime} \mathrm{E}$ & 400 \\
Kladovo & $44^{\circ} 37^{\prime} \mathrm{N}$ & $22^{\circ} 37^{\prime} \mathrm{E}$ & 45 \\
Boljevac & $43^{\circ} 50^{\prime} \mathrm{N}$ & $21^{\circ} 58^{\prime} \mathrm{E}$ & 349 \\
Majdanpek & $44^{\circ} 25^{\prime} \mathrm{N}$ & $21^{\circ} 56^{\prime} \mathrm{E}$ & 340 \\
\hline Timočka Krajina region & $43^{\circ} 20^{\prime}-44^{\circ} 42^{\prime} \mathrm{N}$ & $21^{\circ} 40^{\prime}-22^{\circ} 46^{\prime} \mathrm{E}$ & $35-1978$ \\
\hline
\end{tabular}

Orographic characteristics of this area in northeastern Serbia are shown in Table 2. The largest surface area is found at altitudes from 200 to $500 \mathrm{~m}$. At higher altitudes above $500 \mathrm{~m}$, mountain slopes are very steep. Quality beech wood is preserved in this region (Manojlović, 1986). 
Table 2. Surface elevation zones of Timočka Krajina (\%)

\begin{tabular}{lccccc}
\hline \hline Place & $\begin{array}{c}\mathbf{0}-\mathbf{2 0 0} \\
(\mathrm{m})\end{array}$ & $\begin{array}{c}\mathbf{2 0 0}-\mathbf{5 0 0} \\
(\mathrm{m})\end{array}$ & $\begin{array}{c}\mathbf{5 0 0}-\mathbf{1 0 0 0} \\
(\mathrm{m})\end{array}$ & $\begin{array}{c}\mathbf{1 0 0 0}-\mathbf{1 5 0 0} \\
(\mathrm{m})\end{array}$ & $\begin{array}{c}\mathbf{1 5 0 0}-\mathbf{2 0 0 0} \\
(\mathrm{m})\end{array}$ \\
\hline \hline Bor & 1.38 & 57.22 & 38.96 & 2.44 & 0.00 \\
Kladovo & 51.54 & 46.79 & 1.67 & 0.00 & 0.00 \\
Majdanpek & 9.63 & 58.33 & 32.04 & 0.00 & 0.00 \\
Negotin & 43.51 & 52.68 & 3.80 & 0.01 & 0.00 \\
Zaječar & 21.10 & 71.37 & 7.39 & 0.19 & 0.00 \\
Boljevac & 1.16 & 49.40 & 48.35 & 1.10 & 0.00 \\
Knjaževac & 1.26 & 33.17 & 57.32 & 7.03 & 1.23 \\
Sokobanja & 0.00 & 32.81 & 61.28 & 5.90 & 0.00 \\
\hline
\end{tabular}

\section{Data and methods used}

\subsection{Data}

Daily air temperature [maximum $(T X)$, mean $(T G)$, and minimum $(T N)$ ], precipitation, and relative humidity obtained from three meteorological stations in northeastern Serbia (Fig. 1) were analyzed and compared in order to assess changes in climatic conditions. Data were available from 1961 to 2017 for the meteorological stations in Zaječar and Negotin, and from 1982 to 2017 for the Crni Vrh meteorological station situated at the altitude of 1,037 m (Table 1). Measurements were performed every day without a break using the same type of instruments. The Serbian Meteorological Service made technical and quality control of these measurements.

\subsection{Methods}

As a numerical indicator of the degree of dryness of the climate at a given location, annual values of the De Martonne aridity index (Is) were determined as (De Martonne, 1925):

$$
I S=R R /(T+10),
$$

where $R R$ is the annual sum of precipitation $(\mathrm{mm})$ and $T$ is the mean annual air temperature $\left({ }^{\circ} \mathrm{C}\right)$. Humidity reduces with the decrease in value of $I s$, and vice versa. Climatic classification according to the De Martonne aridity index is shown in Table 3. The De Martonne aridity index was shown to give good results for northern Serbia (Hrnjak et al., 2014) and central Serbia (Radaković et al., 2018), as well as for Greece (Baltas, 2007), Romania (Croitoru et al., 2013), and Spain (Moral et al., 2017). 
Table 3. De Martonne index climatic classification

\begin{tabular}{cl}
\hline \hline Values of $\boldsymbol{I}_{\boldsymbol{S}}$ & \multicolumn{1}{c}{ Climate } \\
\hline \hline$I_{S}<10$ & Arid \\
$10 \leq I_{S}<20$ & Semi-arid \\
$20 \leq I_{S}<24$ & Mediterranean \\
$24 \leq I_{S}<28$ & Subhumid \\
$28 \leq I_{S}<35$ & Humid \\
$35 \leq I_{S} \leq 55$ & Very humid \\
$I_{S}>55$ & Extremely humid \\
\hline
\end{tabular}

The Ångström index (I) was used to assess the risk of forest fires and was calculated as (Chandler et al., 1983):

$$
I=R H / 20+(27-T) / 10,
$$

where $R H$ is the relative humidity (\%) and $T$ is the annual mean air temperature $\left({ }^{\circ} \mathrm{C}\right)$. A reduced index indicates a higher risk of fire (Lukić et al., 2017). The values for $I$ were translated into fire risk as follows:

- when $I>4.0$, fire occurrence was unlikely;

- when $2.5<I \leq 4.0$, fire conditions were unfavorable;

- when $2.0<I \leq 2.5$, fire conditions were favorable; and

- when $I \leq 2.0$, fire occurrence was very likely.

Although the Angström index is a simple day-to-day fire danger indicator, it was successfully applied for different regions in the central part of Europe: Slovakia (Skvarenina et al., 2003), southern Germany (Schunk et al., 2013), Austria (Arpaci et al., 2013), Serbia (Lukić et al., 2017), etc. The Angström index might be a good indicator if there are rapid changes in weather situations, which increase the fire danger situation so quickly, that fuel or soil moisture models are not able to capture that moment (Arpaci et al., 2013).

For this study, we used statistical data about forest fires from the Department for Emergency Situations, Ministry of the Republic of Serbia for the period from 2009 to 2017.

To assess extreme fire danger conditions, we used extreme climate indices selected from the list recommended by the World Meteorological Organization (WMO) - Commission for Climatology and the Research Programme on Climate Variability and Predictability (CLIVAR). This paper concentrates on indices that refer to climate change estimates (conditions suitable for the 
development of fire): the number of summer days (SU25), number of tropical days (SU30), number of tropical nights (TR20), annual maximum of daily maximum temperatures $\left(T X_{x}\right)$, annual minimum of daily minimum temperatures $\left(T N_{n}\right)$, precipitation sum $(\mathrm{mm})$, relative humidity $(R H)$, wet days $(R R l)$, heavy precipitation days $(R R 10)$, maximum number of consecutive dry days $(C D D)$, maximum number of consecutive wet days $(C W D)$, and growing season length (GSL). Definitions of extreme climate indices are given in Alexander et al. (2006) and defined here as follows:

$S U 25$ - number of summer days: annual count of days with $T X>25{ }^{\circ} \mathrm{C}$;

$S U 30$ - number of tropical days: annual count of days when $T X>30^{\circ} \mathrm{C}$;

$T R 20$ - number of tropical nights: annual count of days when $T N>20^{\circ} \mathrm{C}$;

$T X_{x}$ - annual maximum value of daily maximum temperature;

$T N_{n}$ - annual minimum value of daily minimum temperature;

$R R 1$ - wet days: annual count of days with $R R \geq 1 \mathrm{~mm}$;

$R R 10$ - heavy precipitation days: annual count of days when $R R \geq 10 \mathrm{~mm}$;

RRsum - annual precipitation sum;

$R H$ - annual mean relative humidity;

$C D D$ - maximum number of consecutive dry days;

$C W D$ - maximum number of consecutive wet days, and

$G S L$ - growing season length, annual count between first span of at least 6 days with $T G>5^{\circ} \mathrm{C}$ and the first span after July 1 of 6 days with $T G<5{ }^{\circ} \mathrm{C}$.

\section{Results}

\subsection{Climate analysis}

The climate of northeastern Serbia is determined by geographic location, distance from the sea, relief, and forest cover. The climate can be described as moderate-continental with major or minor variations. In the lowest parts of the Negotin region and along the Danube and Timok rivers, there is steppecontinental climate. The characteristics of continental climate are determined by the increase in altitude (Rakićević, 1976). Continentality of the area is reflected in extreme temperatures. During the winter months, air temperature below $-10{ }^{\circ} \mathrm{C}$ can last longer than 10 days.

The average annual temperature is $10.8^{\circ} \mathrm{C}$ in Zaječar, $11.5^{\circ} \mathrm{C}$ in Negotin, and $6.6^{\circ} \mathrm{C}$ in Crni Vrh. The warmest month is July and the coldest month is January (Table 4). Mean annual precipitation is $606.9 \mathrm{~mm}$ in Zaječar, $639.5 \mathrm{~mm}$ 
in Negotin, and $768.2 \mathrm{~mm}$ in Crni Vrh. Maximum precipitation occurs in June or May, while the minimum occurs in January or February (Table 4). Mean annual relative humidity is about $75 \%$, with maximum $R H$ in December and minimum in July or August.

Table 4. Monthly values of mean temperature $(T)$, precipitation sum $(R R)$, and relative humidity $(R H)$ in: Zaječar (ZA), Negotin (NE), and Crni Vrh (CV)

\begin{tabular}{|c|c|c|c|c|c|c|c|c|c|}
\hline \multirow[b]{2}{*}{ Month } & \multicolumn{9}{|c|}{ Station } \\
\hline & \multicolumn{3}{|c|}{$T\left({ }^{\circ} \mathbf{C}\right)$} & \multicolumn{3}{|c|}{$R R(\mathrm{~mm})$} & \multicolumn{3}{|c|}{$R H(\%)$} \\
\hline 1 & -0.9 & -0.4 & -3.3 & 41.6 & 44.4 & 47.7 & 80.1 & 80.4 & 85.2 \\
\hline 2 & 1.2 & 1.6 & -2.6 & 41.1 & 48.8 & 47.2 & 77.5 & 77.6 & 83.7 \\
\hline 3 & 5.7 & 6.3 & 1.0 & 45.0 & 51.4 & 51.2 & 72.5 & 71.1 & 79.0 \\
\hline 4 & 11.4 & 12.0 & 6.4 & 54.3 & 54.4 & 70.6 & 70.0 & 66.7 & 73.8 \\
\hline 5 & 16.4 & 17.2 & 11.2 & 65.1 & 60.6 & 83.6 & 71.3 & 66.7 & 74.4 \\
\hline 6 & 20.0 & 20.8 & 14.5 & 63.8 & 63.9 & 85.0 & 70.4 & 64.5 & 75.3 \\
\hline 7 & 21.8 & 22.7 & 16.8 & 56.8 & 52.0 & 69.2 & 66.7 & 61.3 & 70.9 \\
\hline 8 & 21.2 & 21.9 & 16.8 & 41.2 & 40.8 & 61.6 & 67.6 & 63.0 & 69.5 \\
\hline 9 & 16.5 & 17.3 & 12.2 & 43.1 & 50.3 & 66.9 & 72.3 & 68.8 & 75.4 \\
\hline 10 & 10.6 & 11.2 & 7.0 & 48.6 & 53.5 & 70.0 & 78.2 & 76.1 & 82.3 \\
\hline 11 & 5.3 & 5.8 & 1.9 & 53.0 & 59.5 & 59.0 & 81.2 & 80.7 & 85.1 \\
\hline 12 & 0.7 & 1.3 & -2.0 & 53.2 & 59.8 & 56.1 & 82.1 & 81.7 & 85.7 \\
\hline Average & 10.8 & 11.5 & 6.6 & 606.9 & 639.5 & 768.2 & 74.1 & 71.6 & 78.4 \\
\hline
\end{tabular}

The number of days with an average temperature above $10{ }^{\circ} \mathrm{C}$, namely with temperature conditions suitable for the occurrence of forest fires, is about 200 days in Zaječar and Negotin and about 150 days at Crni Vrh. Mean temperatures above $20^{\circ} \mathrm{C}$ occur in the summer months for about 94 days in Negotin, 65 days in Zaječar, and 21 days in Crni Vrh.

Annual values of the De Martonne index are presented in Table 5. Values of the De Martonne aridity index (Is) point to particularly pronounced low annual values in 2011, when for Zaječar and Negotin, Is values were less than 20, which characterizes these areas as semi-dry. The year 2014 was very humid with $I s$ values greater than 49 (Table 5). 2011 and 2017 were dry years. Very few fires were recorded when conditions were extremely wet, as in 2014. From 2011 to 2013, Is were extremely low, particularly during the active growing season when the occurrence of forest fires is observed.

Climate indices for Negotin, Zaječar, and Crni Vrh for the base period 1961-1990 and the two years 2012 and 2014 are presented in Table 6. 
Table 5. Annual aridity index (Is) according to the De Martonne index

\begin{tabular}{cccccccccc}
\hline \hline \multirow{2}{*}{ Station } & \multicolumn{7}{c}{ Year } \\
\cline { 2 - 10 } & $\mathbf{2 0 0 9}$ & $\mathbf{2 0 1 0}$ & $\mathbf{2 0 1 1}$ & $\mathbf{2 0 1 2}$ & $\mathbf{2 0 1 3}$ & $\mathbf{2 0 1 4}$ & $\mathbf{2 0 1 5}$ & $\mathbf{2 0 1 6}$ & $\mathbf{2 0 1 7}$ \\
\hline \hline Zaječar & 36.7 & 38.0 & 18.0 & 28.0 & 24.6 & 49.0 & 23.7 & 36.1 & 26.5 \\
Negotin & 34.2 & 33.2 & 15.8 & 22.9 & 30.6 & 54.7 & 30.8 & 32.1 & 24.4 \\
CrniVrh & 56.5 & 61.3 & 34.6 & 42.3 & 39.3 & 65.4 & 42.0 & 51.3 & 35.4 \\
\hline
\end{tabular}

Table 6. Climate indices for Negotin, Zaječar, and Crni Vrh for the base period (1961-1990), 2012 and 2014

\begin{tabular}{|c|c|c|c|c|c|c|c|c|c|}
\hline \multirow[b]{2}{*}{ Parameter } & \multicolumn{3}{|c|}{ Negotin } & \multicolumn{3}{|c|}{ Zaječar } & \multicolumn{3}{|c|}{ Crni Vrh } \\
\hline & $\begin{array}{l}1961- \\
1990 \\
\end{array}$ & 2012 & 2014 & $\begin{array}{l}1961- \\
1990 \\
\end{array}$ & 2012 & 2014 & $\begin{array}{l}1961- \\
1990 \\
\end{array}$ & 2012 & 2014 \\
\hline Mean temperature & 11.1 & 13.2 & 12.7 & 10.4 & 11.7 & 11.4 & 6.4 & 7.9 & 7.4 \\
\hline $\begin{array}{l}\text { Absolute } \\
\text { maximum } \\
\text { temperature } T X_{x}\end{array}$ & 41.2 & 40.4 & 34.3 & 41.9 & 40.8 & 33.7 & 33.8 & 32.9 & 27.0 \\
\hline $\begin{array}{l}\text { Absolute minimum } \\
\text { temperature } T N_{n}\end{array}$ & -28.5 & -27.5 & -13.1 & -29.0 & -25.6 & -16.6 & -22.2 & -22.1 & -20.2 \\
\hline Precipitation sum & 646.0 & 532.5 & 1244.8 & 610.5 & 608.7 & 1046.1 & 810.1 & 758.2 & 1137.4 \\
\hline $\begin{array}{l}\text { Tropical nights } \\
T N>20^{\circ} \mathrm{C}\end{array}$ & 1.7 & 13 & 6 & 0.13 & 1 & 0 & $1.6^{*}$ & 12 & 2 \\
\hline $\begin{array}{l}\text { Tropical days } \\
T X>30^{\circ} \mathrm{C}\end{array}$ & 29.1 & 80 & 32 & 28.0 & 80 & 22 & 0.8 & 11 & 0 \\
\hline $\begin{array}{l}\text { Summer days } \\
T X>25^{\circ} \mathrm{C}\end{array}$ & 95.9 & 146 & 99 & 93.8 & 144 & 89 & $13.7^{*}$ & 49 & 5 \\
\hline Relative humidity & 73.1 & 64.3 & 76.5 & 75.6 & 68.5 & 77.9 & 81.8 & 74.1 & 84.9 \\
\hline $\begin{array}{l}\text { Daily maximum of } \\
\text { precipitation }\end{array}$ & 116.3 & 42.8 & 161.3 & 83.1 & 40.5 & 46.5 & 107.0 & 64.7 & 85.8 \\
\hline $\begin{array}{l}\text { Number of days } \\
R R>1.0 \mathrm{~mm}\end{array}$ & 82.0 & 66 & 97 & 82.2 & 78 & 111 & $96.7 *$ & 96 & 125 \\
\hline $\begin{array}{l}\text { Number of days } \\
R R>10.0 \mathrm{~mm}\end{array}$ & 19.4 & 14 & 39 & 19.1 & 17 & 37 & 23.8 & 22 & 33 \\
\hline Sunshine length & 2035.9 & 2582.8 & 1897.8 & 2050.2 & 2144.2 & 1527.4 & 2016.1 & 2400.2 & 1785.3 \\
\hline $\begin{array}{l}\text { Number of clear } \\
\text { days }\end{array}$ & 77 & 133 & 68 & 66.1 & 90 & 32 & 55.7 & 107 & 51 \\
\hline $\begin{array}{l}\text { Number of cloudy } \\
\text { days }\end{array}$ & 110 & 87 & 135 & 113.1 & 101 & 161 & 141.5 & 113 & 152 \\
\hline $\begin{array}{l}\text { Consequtive dry } \\
\text { days } C D D\end{array}$ & 29.5 & 50 & 21 & 29.5 & 46 & 18 & $27.8^{*}$ & 25 & 21 \\
\hline $\begin{array}{l}\text { Consequtive wet } \\
\text { days } C W D\end{array}$ & 6.4 & 6 & 10 & 5.7 & 7 & 5 & $5.3^{*}$ & 7 & 7 \\
\hline $\begin{array}{l}\text { Growing season } \\
\text { length GSL }\end{array}$ & 247.6 & 265 & 280 & 245.7 & 263 & 281 & $200.9^{*}$ & 236 & 219 \\
\hline
\end{tabular}

Numbers with asterics for Crni Vrh are calculated during the period 1982-1990. 
During 2012, a high number of tropical days (about 80) and summer days (about 145) were recorded in Negotin and Zaječar. The number of consequtive dry days $(C D D)$ in 2012 was almost double that of the 1961-1990 baseline period. In contrast to the dry 2012, precipitation sums in 2014 were greater than $1000 \mathrm{~mm}$, which was high even compared to the $600 \mathrm{~mm} \mathrm{1961-1990} \mathrm{annual} \mathrm{baseline.} \mathrm{The}$ observed maximum daily precipitation was $161.3 \mathrm{~mm}$ in Negotin 2014 (Tošić et al., 2017). The number of days when daily precipitation was greater than $10.0 \mathrm{~mm}$ in 2014 was double that of the 1961-1990 baseline (Table 6).

Climate parameters (Table 6) were most impactful to forest ecosystems in 2012 when mean temperature, the number of tropical nights, the number of tropical days (SU30), and the number of summer days (SU25) were highest, and simultaneously the precipitation sum (RRsum), minimum number of wet $(R R I)$ and heavy precipitation (RR10) days were lowest. The number of consequtive dry days $(C D D)$, as well as sunshine length and the number of clear days were highest in 2012. The greatest precipitation, maximum daily precipitation (RR dmax), relative humidity (RH), and number of cloudy days were observed in 2014 at all three stations (Table 6).

Trends for 12 climate indices for Zaječar, Negotin, and Crni Vrh are presented in Table 7. Several indices increased at the 5\% significance level, including SU25, SU30, TX, GSL. Negative trends in $R R 1$ and $R H$ were observed in Zaječar and Negotin. Significant positive trends in SU25, RR10, RRsum, and RRdmax were found at Crni Vrh, which is located at an altitude of 1,037 m.

Table 7. Trend coefficients of climate indices for Zaječar, Negotin, and Crni Vrh

\begin{tabular}{lccc}
\hline \hline Index & $\begin{array}{c}\text { Zaječar } \\
(\mathbf{1 9 6 1 - 2 0 1 7 )}\end{array}$ & $\begin{array}{c}\text { Negotin } \\
(\mathbf{1 9 6 1 - 2 0 1 7 )}\end{array}$ & $\begin{array}{c}\text { Crni Vrh } \\
(\mathbf{1 9 8 2 - 2 0 1 7 )}\end{array}$ \\
\hline \hline$S U 25$ & $\mathbf{0 . 5 5 6 6}$ & $\mathbf{0 . 4 8 2 1}$ & $\mathbf{0 . 5 0 3 3}$ \\
$S U 30$ & $\mathbf{0 . 6 7 8 1}$ & $\mathbf{0 . 6 2 6 6}$ & 0.0400 \\
$T X_{x}$ & $\mathbf{0 . 0 5 8 8}$ & $\mathbf{0 . 0 5 2 0}$ & 0.0147 \\
$T N_{n}$ & 0.0178 & 0.0537 & -0.0393 \\
$R R 1$ & -0.0731 & $\mathbf{- 0 . 2 5 6 8}$ & 0.3921 \\
$R R 10$ & 0.0152 & 0.0573 & $\mathbf{0 . 2 9 5 6}$ \\
$R R s u m$ & 0.3722 & 0.5831 & $\mathbf{6 . 6 3 4 3}$ \\
$R R d m a x$ & 0.0914 & 0.4934 & $\mathbf{0 . 7 7 2 4}$ \\
$R H$ & $\mathbf{- 0 . 0 9 3 0}$ & $\mathbf{- 0 . 0 9 7 8}$ & -0.0137 \\
$C D D$ & -0.0006 & 0.1121 & -0.2045 \\
$C W D$ & 0.0091 & $\mathbf{- 0 . 0 0 3 1}$ & 0.0556 \\
$G S L$ & $\mathbf{0 . 4 9 3 4}$ & $\mathbf{0 . 8 1 3 1}$ & 0.4082 \\
\hline
\end{tabular}

Coefficients being significant at the $5 \%$ level are indicated by bold. 


\subsection{Analysis of forest fires in Timočka Krajina}

The occurrence of forest fires in the Timočka Krajina region changes from period to period. The number of forest fires in the territory of Timočka Krajina and Zaječar during the period 2009-2017 is shown in Fig. 2. There was a marked difference in the number of fires in 2012 compared to 2014. Namely, during 2014 only one/zero fire was registered in the Timočka Krajina region/Zaječar, while in 2012, 69/17 fires were recorded.

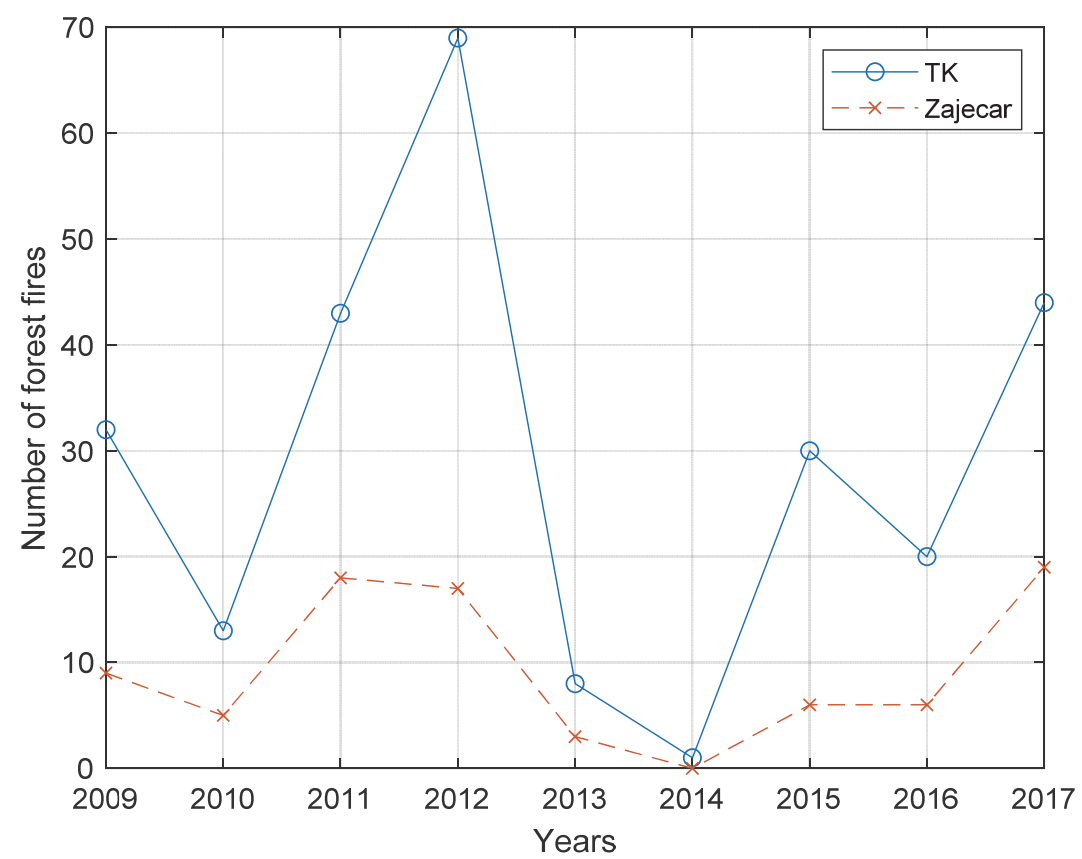

Fig. 2. Number of total forest fires at the territory of Timočka Krajina (TK) and Zaječar during the period 2009-2017.

Daily fluctuations of the Ångström index for Negotin, Zaječar, and Crni Vrh in 2012 and 2014 are presented in Fig. 3. The Ångström index was lower during 2012 indicating that the risk of fire was elevated. For a long period during the growing season of 2012, the Angström indices were lower than 2.5. The lowest value of the Angström index (1.02) was observed on September 2, 2012 at Crni Vrh. The longest period with an Ångström index less than 2.5 was in the period from June 21 to July 22, 2012 in Negotin. The Ångström index in 2014 was above 3 , which means that the risk of fire was significantly lower in 2014 (Fig. 3). 

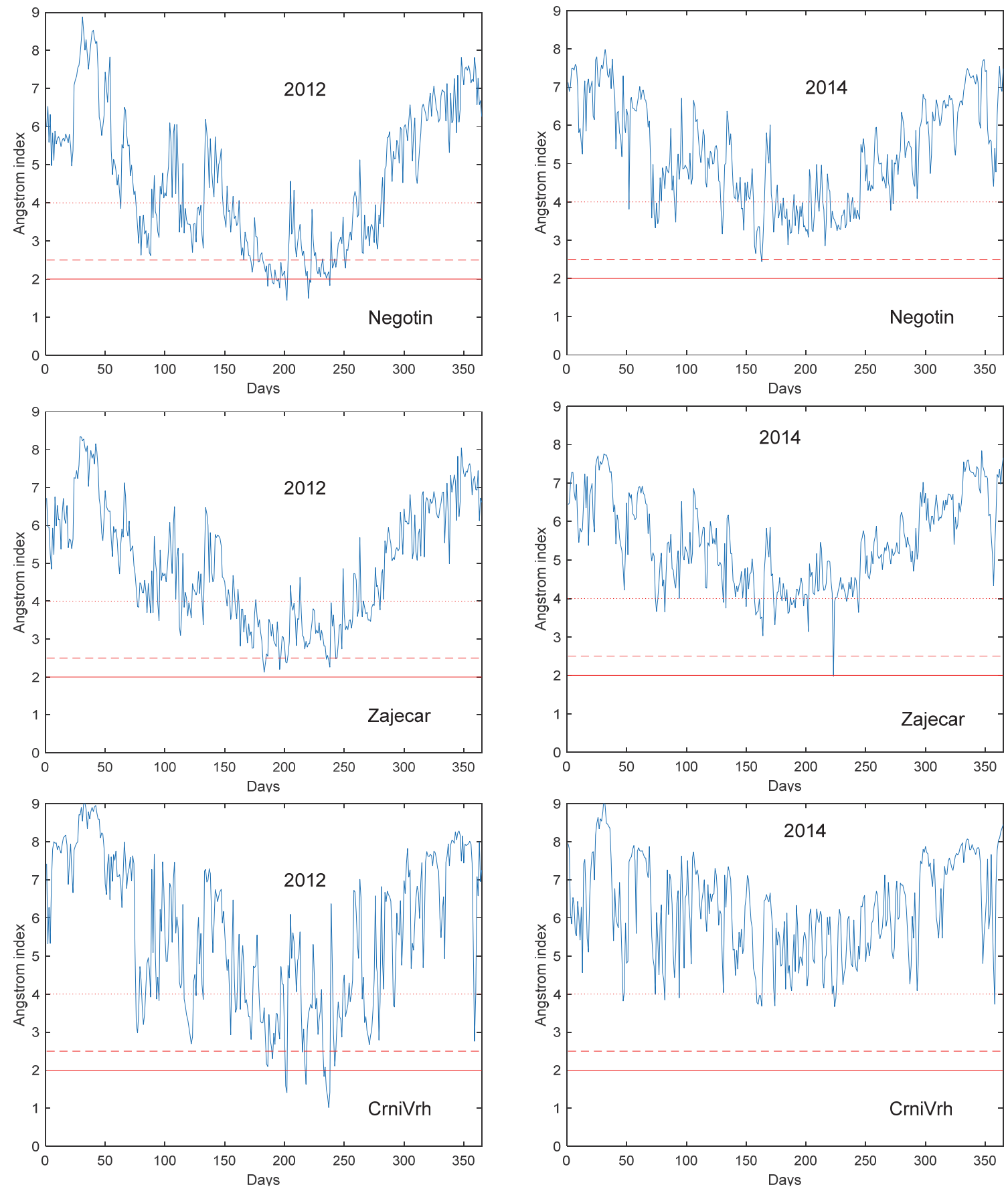

Fig. 3. Time series of the Ångström index for Negotin, Zaječar, and Crni Vrh in 2012 (left) and 2014 (right) with fire danger classes $I=2.0$ (noted by horizontal solid line), $I=2.5$ (dashed line), and $I=4.0$ (dotted line).

\section{Discussion}

This study was motivated by an interest in examining the influence of extreme climate conditions on forest fire risk in northeastern Serbia. A significant increase in summer and tropical days, absolute maximum temperature, and growing season length, and a significant decrease in relative humidity was found 
in Zaječar and Negotin. A significant increase in summer days and precipitation indices was found for Crni Vrh. According to the meteorological station in Crni Vrh, this location was considered very humid, which is explained by the high altitude of the station in the Carpathian Mountains (Radaković et al., 2018).

Previous studies of changes in air temperature in Serbia, both average annual and seasonal air temperatures, have clearly indicated an increase (e.g., Gavrilov et al., 2016). The observed warming was also confirmed by the increased frequency of warm extremes (Unkašević and Tošić, 2013). The changes taking place were also documented for the whole of Europe (Klein Tank and Können, 2003; Della-Marta et al., 2007; Shevchenko et al., 2014; Tomczyk et al., 2019) and globally (e.g., Alexander et al., 2006).

The highest number of tropical nights, number of tropical days, number of summer days, number of consequtive dry days, and the lowest precipitation sums, minimum number of wet and heavy precipitation days were registered in 2012. All these conditions were favorable for the development of fires. The Balkans and the central part of Europe were affected by unprecedented drought in the summer of 2012 (Unkašević and Tošić, 2015). The longest heat waves, caused by the flow of warm and dry air from North Africa towards southeastern Europe, were observed during the summer of 2012 in Serbia at ten out of 15 stations (Unkašević and Tošić, 2015). More than 1,000 forest fires occurred in Serbia in 2012 (Lukić et al., 2017). The highest number of fires was recorded in 2012 , creating the greatest damage with 7,460 ha and $63,118 \mathrm{~m}^{3}$ wood mass burned (Šorak and Rvović, 2016).

The year 2014 was one of the wettest recorded in Serbia (Tošić et al., 2017). The highest values of precipitation sums, daily maximum of precipitation, relative humidity, and number of cloudy days were observed in 2014 at all three stations considered. Precipitation was high during the vegetation period in 2014, and the number of forest fires was smallest.

As a measure of fire risk, the Ångström index provides good results even when using only meteorological variables. Ångström index values in 2012 were below 2.5, indicating favorable fire conditions, while in 2014 they were above 3, indicating that the risk of fire was significantly lower. Replacing $T X$ instead of $T G$ in definition of the Angström index provides better results. Values of the Angström index were below 2 for Zaječar (Fig. 4), indicating very favorable fire conditions during the summer of 2012 when 17 forest fires were recorded (Fig. 3). In addition, the minimum Ångström index value was not below 2 (Fig. 4) compared to 2014 (Fig. 3) when no forest fires were registered in Zaječar (Fig. 2). 

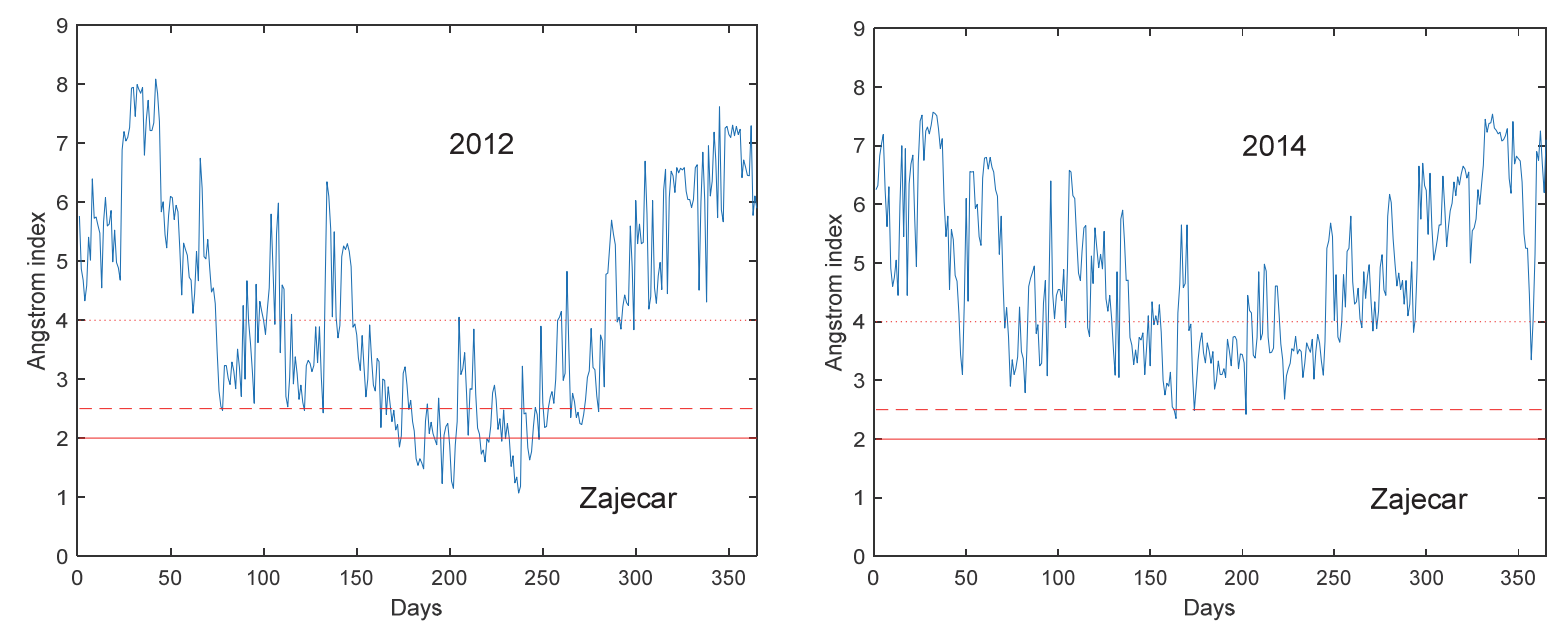

Fig. 4. Time series of the Ångström index (with $T X$ instead of $T G$ ) for Zaječar in 2012 (left) and 2014 (right) with fire danger classes $I=2.0$ (noted by horizontal solid line), $I=2.5$ (dashed line), and $I=4.0$ (dotted line).

Živanović et al. (2020) suggested that increased air temperature and reduced precipitation in the period 1981-2010 compared to the period 19611990 had substantial influence on the probability of fire occurrence in Serbia. They have also concluded that particular attention has to be paid to the eastearn and southearn parts of Serbia, where the decrease in precipitation was greatest.

\section{Conclusions}

Extreme climate conditions are crucial for forecasting and managing forest potential in Serbia, and posing a challenge for policy makers. If extreme climate effects are implemented in risk assessments of forest fires, adverse effects can be minimized. Many climate scenarios predict further increases in the frequency of climate extremes in the future, and it is necessary to take adequate measures to adapt.

Our research reveals that understanding extreme climate conditions and their impact on the occurrence of forest fires are important variables to consider when selecting adaptation strategies. Determining priorities for adaptation measures and their implementation are of great importance. Forest protection should be based on good organization and a hierarchy of responsibility for planning and implementing preventive and repressive measures to protect forests from fire. Evaluation of impacts of extreme climate conditions that are conducive to the emergence and spread of forest fires has particular importance. Synoptic situation unfavorable to the occurrence of forest fires are those that 
occur because of long dry periods with high air temperatures and low relative humidity. Our study showed that the Ångström index calculated with meteorological variables only provided a good indicator for forecasting forest fires. Better results were obtained when the daily maximum temperature instead of daily mean temperature were included in the definition of the Angström index. The competent authorities for the protection of forests against fire in Serbia should define indices to assess climate extremes that can be used to estimate conditions indicative of extreme fire danger (with the levels of risk of danger). Successful implementation of the strategies for adaptation to extreme climate conditions should lead to the active promotion and education of the population by the competent institutions.

Acknowledgements: This study was supported by the Serbian Ministry of Science, Education and Technological Development, under Grant No. 176013. The authors appreciate the efforts of anonymous reviewer in improving this manuscript.

\section{References}

Aleksić, V., Milutinović, S., Marić, M. and Đorđević, N., 2004: Drought in the Timok region and its impact on crop production. Proceedings of the Conference with international participation 'Ecological truth', Borsko jezero, 224-228.

Alexander, L., Zhang, X., Peterson, T.C., Caesar, J., Gleason, B., Klein Tank, A.M.G., Haylock, M., Collins, D., Trewin, B., Rahimzadeh, F., Tagipour, A., Rupa Kumar, K., Revadekar, J., Griffiths, G., Vincent, L., Stephenson, D.B., Burn, J., Aguilar, E., Brunet, M., Taylor, M., New, M., Zhai, P., Rusticucci, M. and Vazquez-Aguirre, J.L., 2006: Global Observed Changes in Daily Climate Extremes of Temperature and Precipitation. J. Geophys. Res. 111, D05109. https://doi.org/10.1029/2005JD006290

Arpaci, A., Eastaugh, C.S., and Vacik, H., 2013: Selecting the best performing fire weather indices for Austrian ecoregions. Theor. Appl. Climatol. 114, 393-406. https://doi.org/10.1007/s00704-013-0839-7

Baltas, E., 2007: Spatial distribution of climatic indices in northern Greece. Meteorol. Appl. 14, 6978. https://doi.org/10.1002/met.7

Bartholy, J. and Pongrácz, R., 2007: Regional analysis of extreme temperature and precipitation indices for the Carpathian Basin from 1946 to 2001. Glob. Planet. Change 57, 83-95. https://doi.org/10.1016/j.gloplacha.2006.11.002

Chandler, C., Cheney, P., Thomas, P., Trabaud, L., and Williams, D., 1983: Fire in forestry. Vol. I, John Wiley \& Sons. Inc., Canada.

Carnicer, J., Coll, M., Ninyerola, M., Pons, X., Sanchez, G., and Penuelas, J., 2011: Widespread crown condition decline, food web disruption, and amplified tree mortality with increased climate change-type drought. Proceedings of the National Academy of Science of USA (PNAS) 108, 1474-1478. https://doi.org/10.1073/pnas.1010070108

Croitoru, A.E., Piticar, A., Imbroane, A.M. and Burada, D.C., 2013: Spatiotemporal distribution of aridity indices based on temperature and precipitation in the extra-Carpathian regions of Romania. Theor. Appl. Climatol. 112, 597-607. https://doi.org/10.1007/s00704-012-0755-2

De la Cruz, A., Gil, P.M., Fernandez-Cancio, A., Minaya, M., Navaro-Cerrillo, R.M., SanchezSalguero, R., and Grau, J.M., 2014: Defoliation triggered by climate induced effects in Spanish ICP Forests monitoring plots. Forests Ecol. Manag. 331, 245-255. https://doi.org/10.1016/j.foreco.2014.08.010

De Martonne, E., 1925: Traité de géographie physique, Vol. I: Notions generales, climat, hydrographie. Geogr. Rev. 15, 336-337. 
Della-Marta, P. M., Haylock, M. R., Luterbacher, J., and Wanner, H., 2007: Doubled length of western European summer heat waves since 1880. J. Geophys. Res., 112, D15103 https://doi.org/10.1029/2007JD008510

Djurdjević, V., Vuković, A., and Vujadinović-Mandić, M., 2015: Climate change scenarios - impacts and adaptation. Proceedings: Planska i normativna zaštita prostora i životne sredine, 16-18 April 2015, Subotica, Serbia, 29-35.

Easterling, D.R., Meehl, G.A., Parmesan, C., Chagnon, S.A., Karl, T., and Mearns, L.O., 2000: Climate extremes: Observation, modelling and impacts. Science 289, 2068-2074. https://doi.org/10.1126/science.289.5487.2068

Finkel, J.M. and Katz, J.I., 2018: Changing world extreme temperature statistics. Int. J. Climatol. 38, 2613-2617. https://doi.org/10.1002/joc.5342

Gavrilov, M.B., Tošić, I., Unkašević, M., Marković, S.B., and Petrović, P., 2016: The analysis of annual and seasonal temperature trends using the Mann-Kendall test in Vojvodina, Serbia. Idöjárás 120, 183-198.

Hrnjak, I., Lukić, T., Gavrilov, M.B., Marković, S.B., Unkašević, M. and Tošić, I., 2014: Aridity in Vojvodina, Serbia. Theor. Appl. Climatol. 115, 323-332. https://doi.org/10.1007/s00704-013-0893-1

IPCC, 2007: Climate change 2007. Impacts, adaptation and vulnerability. Cambridge University press. New York, USA.

Kadović, R. and Medarević, M., 2007: Forests and climate change. Proceedings of papers, Ministry of agriculture, forestry and water management of Republic of Serbia, Faculty of Forestry, Belgrade, 1-206.

Keeley, J.E., 2004: Impact of antecedent climate on fire regimes in coastal California. Inter. J. Wildland Fire 13, 173-182. https://doi.org/10.1071/WF03037

Klein Tank, A.M.G., and Können, G.P., 2003: Trends indices of daily temperature and precipitation extremes in Europe, 1946-99. J. Climatol., 16: 3665-3680. https://doi.org/10.1175/1520-0442(2003)016<3665:TIIODT>2.0.CO;2

Lukić, T, Marić, P, Hrnjak, I, Gavrilov, M.B, Mlađan, D, Zorn, M, Komac, B, Milošević, Z, Marković, S.B, Sakulski, D, Jordaan, A, Đorđević, J, Pavić, D. and Stojsavljević, R., 2017: Forest fire analysis and classification based on a Serbian case study. Acta Geogr. Slov. 57, 1-13. https://doi.org/10.3986/AGS.918

Manojlović, P., 1986: Severoistočna Srbija-fizičko-geografske karakteristike. Istorijski arhiv Krajine, Ključa i Poreča, Negotin (in Serbian).

McKenzie, D., Gedalof, Z., Peterson, D.L., and Mote, P., 2004: Climatic change, wildfire, and conservation. Conserv. Biol. 18, 890-902. https://doi.org/10.1111/j.1523-1739.2004.00492.x

Moral, F.J., Paniagua, L.L., Rebollo, F.J., and Garcia-Martín, A., 2017: Spatial analysis of the annual and seasonal aridity trends in Extremadura, southwestern Spain. Theor. Appl. Climatol. 130, 917-932. https://doi.org/10.1111/j.1523-1739.2004.00492.x

Moritz, M.A., 2003: Spatio-temporal analysis of controls on shrubland fire regimes: age dependency and fire hazard. Ecology 84, 351-361. https://doi.org/10.1890/0012-9658(2003)084[0351:SAOCOS]2.0.CO;2

Popović, T., Radulović, E., and Jovanović, M.M., 2005: How much is changing climate, what will be our future climate? EnE05 - Conference Environment towards Europe, Belgrade, 212-218.

Popović, T., Živković, M., and Radulović, E., 2008: Serbia and global warming. Sustainable development and climate change, Niš, June 2008, 47-54.

RZS, 2008: Statistical office of the Republic of Serbia, Statistical Yearbook, Belgrade, 2002-2008.

Radaković, M., Tošić, I., Bačević, N., Mladjan, D., Gavrilov, M.B. and Marković, S., 2018: The analysis of aridity in Central Serbia from 1949 to 2015. Theor. Appl. Climatol. 133, 887-898. https://doi.org/10.1007/s00704-017-2220-8

Rakićević, T., 1976: Climate characteristics of Eastern Serbia. Journal of the Geographical Institute "Jovan Cvijić" SASA 28, 41-67.

Santos, C.A.C., Neale, C.M.U., Raoa, T.V.R. and da Silva, B.B., 2011: Trends in indices for extremes in daily temperature and precipitation over Utah, USA. Int. J. Climatol. 31, 1813-1822.

https://doi.org/10.1002/joc.2205 
Schunk C., Wastl C., Leuchner M., Schuster C., and Menzel A., 2013: Forest fire danger rating in complex topography - results from a case study in the Bavarian Alps in autumn 2011. Nat. Hazards Earth Syst. Sci. 13, 2157-2167. https://doi.org/10.5194/nhess-13-2157-2013

Seidling, $W ., 2007$ : Signals of summer drought in crown condition data from the German Level I network. Eur. J. For. Res. 126, 529-544. https://doi.org/10.1007/s10342-007-0174-6

Skvarenina, J., Mindas, J., Holecy, J., and Tucek, J., 2003: Analysis of the natural and meteorological conditions during two largest forest fire events in the Slovak Paradise National Park. In: Forest Fire in the Wildland-Urban Interface and Rural Areas in Europe: An Integral Planning and Management Challenge, Institute of Mediterranean Forest Ecosystems and Forest Products Technology, Athens, Greece, 15-16 May 2003, 29-36.

Shevchenko, O., Lee, H., Snizhko, S., and Mayer, H., 2014: Long-term analysis of heat waves in Ukraine. Int. J. Climatol. 34, 1642-1650. https://doi.org/10.1002/joc.3792

Stevanović, V., 1999: Red Book of Flora of Serbia. Institute for Nature Conservation of Serbia, Belgrade.

Šrak, $R$. and Rvović, I., 2016: A damage analysis of wildfires in the Republic of Serbia for the 20102014 period. Res. Rev. Dep. Geogr. Tourism Hotel Manage. 45, 1-10.

Tabaković-Tošić, M., Marković, M., Rajković, S. and Veselinović, M., 2009: Wildfires in Serbia chance or frequent phenomenon. Sustainable forestry, Proceedings 59-60, Institute for Forestry, Belgrade, 97-125.

Tomczyk, A.M., Kendzierski, S., Kugiejko, M., and Pilguj, N., 2019: Thermal conditions in the summer season on the Polish coast of the Baltic Sea in 1966-2015. Idöjárás 123, 57-72. https://doi.org/10.28974/idojaras.2019.1.4

Tošić, I., Unkašević, M., and Putniković, S., 2017: Extreme daily precipitation: the case of Serbia in 2014. Theor. Appl. Climatol. 128, 785-794. https://doi.org/10.1007/s00704-016-1749-2

Unkašević, M. and Tošić, I., 2013: Trends in temperature indices over Serbia: relationships to largescale circulation patterns. Int. J. Climatol. 33, 3152-3161. https://doi.org/10.1002/joc.3652

Unkašević, M. and Tošić, I., 2015: Seasonal analysis of cold and heat waves in Serbia during the period 1949-2012. Theor. Appl. Climatol. 120, 29-40. https://doi.org/10.1007/s00704-014-1154-7

Vasić M., 1992: Wildfires. University of Belgrade, Faculty of Forestry, Belgrade, p.105.

Vuković, A., Vujadinović, M., Rendulić, S., Djurdjević, V., Ruml, M., Babić, V., and Popović, D., 2018: Global Warming Impact on Climate Change in Serbia for the period 1961-2100. Therm. Sci. 22, (6A), 2267-2280. https://doi.org/10.2298/TSCI180411168V

Yan, Z., Jones, P.D., Davies, T.D. et al. (2002) Trends of extreme temperatures in Europe and China based on daily observations. Clim. Chang 53, 355-392.

https://doi.org/10.1007/978-94-010-0371-1_13

Živanović, S., 2012: Analysis of climate change elements to prediction of forest fires. Topola 189/190, $163-170$.

Živanović, S., 2015: Evaluating the impact of climate vulnerability of forest fire. Acta Agriculturae Serbica, Vol. XX, 39, 17-28. https://doi.org/10.5937/AASer1539017Z

Živanović, S., Gocić, M., Ivanović, R. and Martić-Bursać, N., 2015: The effect of air temperature on forest fire risk in the municipality of Negotin. Bull. Serbian Geograph. Soc. 95, 67-76. https://doi.org/10.2298/GSGD1504067Z

Živanović, S., 2017: Impact of drought in Serbia on fire vulnerability of forests. Int. J. Bioautomation 21, 217-226.

Živanović, S., Gocić, J.M., Vukin, M. and Babić, V., 2018: The importance of the knowledge of the effects of moisture conditions on the frequency and intensity of forest fires. Forestry, University of Belgrade-Faculty of Forestry, LXX (3-4), 127-136.

Živanović, S., Ivanović, R., Gocić, M., Đokić, M. and Tošić, I., 2020: Influence of air temperature and precipitation on the risk of forest fires in Serbia. Meteorol. Atmos. Phys. In Press.

https://doi.org/10.1007/s00703-020-00725-6 